\title{
Isolation and Some Properties of Two Kinds of Cytochrome $c$ Oxidase from Iron-grown Thiobacillus ferrooxidans
}

\author{
Tsuyoshi Sugio, Tatsuo Tano and Kazutami IMAI \\ Department of Agricultural Chemistry, Faculty of Agriculture, \\ Okayama University, Okayama 700, Japan
}

Received November 14, 1980

\begin{abstract}
Two kinds of cytochrome $c$ oxidase were partially purified from iron-grown $T$. ferrooxidans. The first type (cytochrome $c$ oxidase I) was easily solubilized without a detergent and had a $\mathrm{pH}$ optimum at 3.0. The other (cytochrome $c$ oxidase II) which was bound tightly to the cell membrane and solubilized with sodium dodecyl sulfate had a pH-optimum at 5.2. Each type was heat-sensitive and inhibited by cyanide and azide. Since the $\mathrm{pH}$ level of the bacterial iron oxidizing activity corresponded closely with the $\mathrm{pH}$ of cytochrome $c$ oxidase I but not cytochrome $c$ oxidase II, it was proposed that the former may play an important role in the iron oxidizing system.
\end{abstract}

The respiratory chain component of the iron-oxidizing bacterium, $T$. ferrooxidans, has been investigated by several workers. ${ }^{1 \sim 11}$ ) Though cytochrome $c$ oxidase is one of the most important components in the ironoxidizing system of the bacterium, there have only been a few reports on the enzyme. Blaylock and Nason ${ }^{2)}$ demonstrated activity in a particulate iron oxidase system of Ferrobacillus ferrooxidans. We also observed this activity not only in the particulate fraction, but also in the $105,000 \times g$ soluble fraction. ${ }^{9)}$ Recently Ingledew and Cobley reported the presence of two cytochrome $a_{1}$ in the bacterium by using optical techniques and proposed a model for the sequence of the respiratory chain components. ${ }^{6,8)}$ The present paper describes the solubilization, partial purification, and preliminary characterization of two kinds of cytochrome $c$ oxidase from irongrown $T$. ferrooxidans. The roles of the two enzymes in the bacterium were also discussed.

\section{MATERIALS AND METHODS}

Microorganism. Iron-oxidizing bacterium, $T$. ferrooxidans, was used throughout this study and was the same as that previously described by Imai et al. ${ }^{12)}$

Media and conditions of cultivation. The organism was grown on three types of the medium: (a) $9 \mathrm{~K}$ medium $^{13}$ ) containing ferrous iron as the sole energy source was used for autotropic type of culture; (b) $9 \mathrm{~K}$-glucose medium containing glucose in the $9 \mathrm{~K}$ medium was used for mixotrophic type of culture; and (c) glucose-salt medium containing $0.5 \%$ glucose and salt of $9 \mathrm{~K}$ medium (except iron) was used for heterotrophic culture. In large-scale production of autotrophically grown cells which were used for the purification of two kinds of cytochrome $c$ oxidase, 9 liters of $9 \mathrm{~K}$ medium in a 10 liter carboy was inoculated with 1 liter of the activity growing autotrophic culture and cultured under aeration at $28^{\circ} \mathrm{C}$ for 120 hours. About 60 liters of culture from six carboys were filtered with Toyo filter paper (No. 2) in order to remove the bulk of ferric precipitates and centrifuged with a Hitachi 18 PR-3 continuous flow roter $(15,000 \times \mathrm{g} / \mathrm{min}$, and a flow rate of $200 \mathrm{ml} / \mathrm{min}$ ) to yield a cell paste with about 1.5 grams of protein.

Iron-oxidizing activity. Iron-oxidizing activity was determined by oxygen uptake, caused by the oxidation of ferrous ion, in a Warburg manometer as described previously: ${ }^{12\}}$

Cytochrome $c$ oxidizing activity. The activity of cytochrome $c$ oxidase was measured by two methods. (a) It was measured by tracing the rate of reoxidation of reduced $c$ type cytochrome with oxygen. We previously showed that $c$ type cytochrome on the cytoplasmic membrane of this bacterium was reduced with ferrous sulfate in acidic and anaerobic conditions. ${ }^{12)}$

A Thunberg type cuvette was used in this experiment. The composition of the reaction mixture was (total volume, $3.0 \mathrm{ml}$ ): in main chamber-buffer solution, $200 \mu \mathrm{mol}$; cell-free crude extract, which was oxidized with potassium ferricyanide and dialyzed with $0.01 \mathrm{M}$ phosphate buffer, $\mathrm{pH} 7.5,20 \mathrm{mg}$ of protein, and in side arm-ferrous sulfate, 
$0.4 \mu \mathrm{mol}$ (pH 3.5 with sulfuric acid). The cuvette was evacuated at $4^{\circ} \mathrm{C}$ and filled with nitrogen gas. This operation was repeated three times and finally the cuvette was filled with nitrogen gas. After 10 minute equilibration at $25^{\circ} \mathrm{C}$, ferrous sulfate solution was added from the side arm to the main chamber, and the spectrum of the reaction mixture was measured immediately after the addition and at intervals of about 15 minutes with a Shimadzu MPS-50L recording spectrophotometer. After confirming that the cytochrome was retained in reduced form, an aerobic condition was made by opening the cuvette. After that, the spectrum was measured immediately and at intervals of 30 minutes. The activity was expressed by the difference in absorbance between $552 \mathrm{~nm}$ and $538 \mathrm{~nm}$ of $c$ type cytochrome per $20 \mathrm{mg}$ of protein per minute.

(b) The second method was the photochemical measuring of the decrease in absorbance at $550 \mathrm{~nm}$ of reduced mammalian cytochrome $c$. The composition of the reaction mixture was as follows: buffer solution, $200 \mu \mathrm{mol}$; glycerol, $0.5 \mathrm{ml}$; enzyme solution; total volume $2.8 \mathrm{ml}$. The same concentration of the 10 minute boiled enzyme solution was used in each control for exclusion of chemical oxidation of reduced cytochrome $c$. After 5 minutes equilibration of the mixture at $25^{\circ} \mathrm{C}, 0.2 \mathrm{ml}$ of reduced mammalian cytochrome $c$ (Sigma type IIA) solution was added at a concentration of $4 \mu \mathrm{M}$, and the reaction was started. Absorbance at $550 \mathrm{~nm}$ was immediately traced with a Shimadzu MPS-50L recording spectrophotometer. The activity was expressed by the difference in absorbance at $550 \mathrm{~nm}$ between the active and boiled fraction per $\mathrm{mg}$ protein per minute.

Glucose oxidizing activity. Glucose oxidizing activity was determined by the oxygen uptake caused by oxidation of glucose in a Warburg manometer. Each vessel contained $3.0 \mathrm{ml}$ of liquid volume plus $0.2 \mathrm{ml}$ of $20 \%$ potassium hydroxide in the center well. The gas phase was air and the temperature, $30^{\circ} \mathrm{C}$. The composition of the reaction mixture was as follows (in $3.0 \mathrm{ml}$ ): glucose, $100 \mu \mathrm{mol}$; cell-free extracts, $20 \mathrm{mg}$ of protein; phosphate buffer, $\mathrm{pH} 6.0,200 \mu \mathrm{mol}$. Data were corrected for endogenous respiration. The activity was expressed by the amount of $\mathrm{O}_{2}$ uptake $(\mu 1)$ per mg protein per minute.

Protein determination. The protein content was determined by the method of Lowry et al ${ }^{14)}$ using crystalline bovine serum albumin as the reference protein.

\section{RESULTS}

\section{Effects of $p H$ on the activity of cytochrome $c$} oxidase

Cytochrome $c$ oxidase of crude cell-free extracts was measured by two distinct methods as described in MATERIALS AND

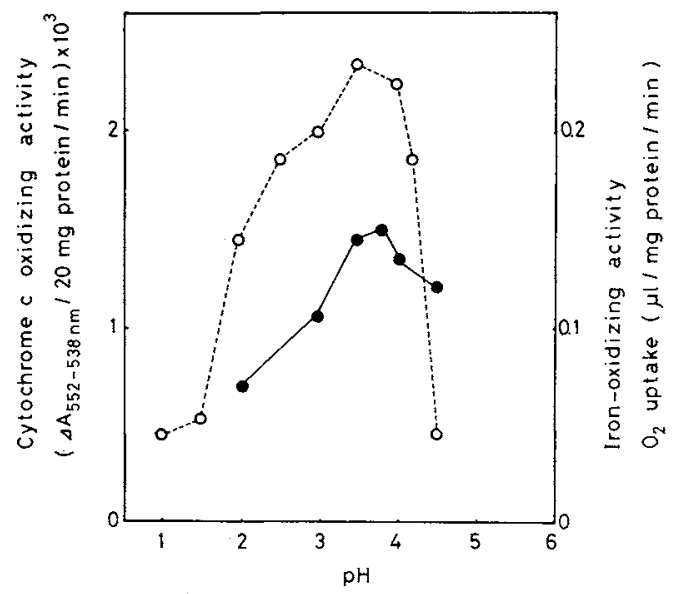

Fig. 1. Effect of $\mathrm{pH}$ on the Activity of Cytochrome $c$ Oxidase of Crude Cell-free Extracts in $0.1 \mathrm{~m} \beta$-Alanine Sulfuric Acid Buffer.

The activity of cytochrome $c$ oxidase (-) was measured in $0.1 \mathrm{M} \beta$-alanine sulfuric acid buffer by tracing the rate of reoxidation of the reduced membrane bound $c$ type cytochrome (Method I) as described in MATERIALS AND METHODS. Effect of $\mathrm{pH}$ level on the activity of iron-oxidase ( $\bigcirc--\bigcirc)$ was also measured in the buffer.

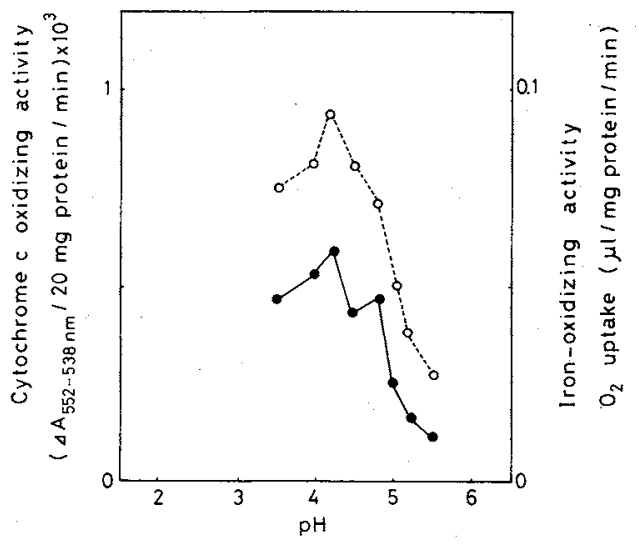

Fig. 2. Effect of $\mathrm{pH}$ Level on the Activity of Cytochrome $c$ Oxidase of Crude Cell-free Extracts in $0.1 \mathrm{~m}$ Acetate Buffer.

The activity of cytochrome $c$ oxidase (-) was measured in $0.1 \mathrm{M}$ acetate buffer by tracing the rate of reoxidation of the reduced membrane bound $c$ type cytochrome (Method I) as described in MATERIALS AND Methods. Effect of $\mathrm{pH}$ on the activity of iron-oxidase (O---O) was also measured in the buffer.

Methods. The rate of reoxidation of the reduced membrane bound $c$ type cytochrome was measured as cytochrome $c$ oxidase (Figs. 1 
and 2). The pH-optimum of cytochrome $c$ oxidase was 3.8 in $0.1 \mathrm{M} \beta$-alanine-sulfuric acid buffer (Fig. 1). Effect of $\mathrm{pH}$ on the activity of iron-oxidase was also measured in the same buffer, and its pH-optimum lay between 3.5 and 4.0 , which was coincided closely with that of cytochrome $c$ oxidase. Two $\mathrm{pH}$ activity peaks of cytochrome $c$ oxidase were observed in $0.1 \mathrm{M}$ acetate buffer (Fig. 2). One showed high activity at $\mathrm{pH} \mathrm{4.2,} \mathrm{the} \mathrm{other} \mathrm{showed} \mathrm{a} \mathrm{low}$ activity at $\mathrm{pH}$ 4.8. Iron-oxidizing activities were also measured in the buffer. The pHoptimum of iron-oxidase was 4.2 , which was also coincided well with that of the higher activity peak of cytochrome $c$ oxidase. From the results it can be said that the cytochrome $c$ oxidase with a $\mathrm{pH}$-optimum at $\mathrm{pH} 3.8$ in $0.1 \mathrm{M}$ $\beta$-alanine sulfuric acid buffer or at $\mathrm{pH} 4.2$ in $0.1 \mathrm{M}$ acetate buffer plays an important role in the iron-oxidizing system. The $\mathrm{pH}$-activity peak of iron-oxidase in $0.1 \mathrm{M}$ acetate buffer shifted slightly to higher $\mathrm{pH}$ in comparison with the result obtained in $0.1 \mathrm{M} \quad \beta$-alanine sulfuric acid buffer, which is discussed later in

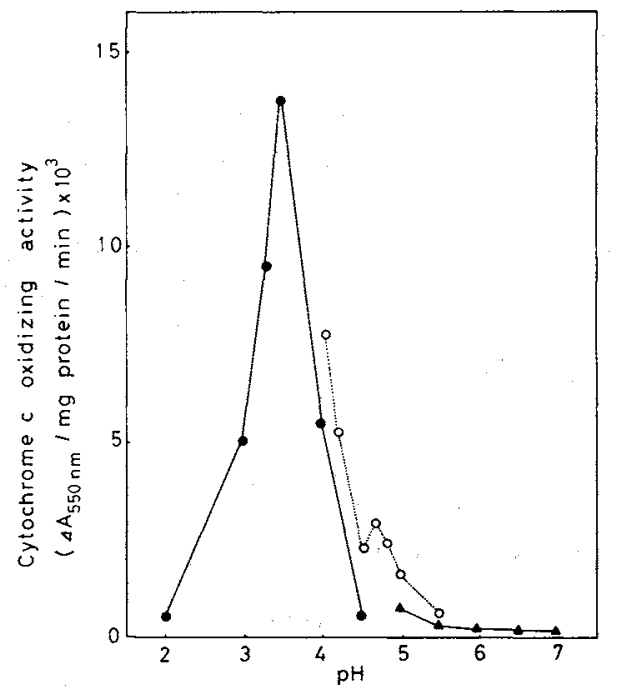

FIG. 3. Effect of $\mathrm{pH}$ Level on the Activity of Cytochrome $c$ Oxidase of Crude Cell-free Extracts.

The activity of cytochrome $c$ oxidase was determined by measuring the decrease in absorbance at $550 \mathrm{~nm}$ of reduced mammalian cytochrome $c$ (Method 2) as described in Materials and Methods. - $0.1 \mathrm{M} \beta$-Alanine sulfuric acid buffer; $\bigcirc--\bigcirc, 0.1 \mathrm{~m}$ Acetate buffer;

$0.1 \mathrm{M}$ Potassium phosphate buffer. the text in relation to the $\mathrm{pH}$-activity peak of the partially purified cytochrome $c$ oxidase $I$.

The activity of cytochrome $c$ oxidase was also measured by tracing the decrease in absorbance at $550 \mathrm{~nm}$ of reduced mammalian cytochrome $c$. Since chemical oxidation of reduced mammalian cytochrome $c$ was high at low $\mathrm{pH}, 10$ minute boiled enzyme solution was always used in each control to exclude chemical oxidation. Two $\mathrm{pH}$ activity peaks of cytochrome $c$ oxidase were also observed in this case (Fig. 3). One showed a high activity peak at $\mathrm{pH} 3.5$ in $0.1 \mathrm{M} \beta$-alanine-sulfuric acid buffer; the other showed a low activity peak at $\mathrm{pH}$ 4.6 in $0.1 \mathrm{M}$ acetate buffer. Little or no activity was observed at above $\mathrm{pH} 6.0$. These results suggest that two kinds of cytochrome $c$ oxidase may be present in the cell. These cytochrome $c$ oxidases are tentatively called cytochrome $c$ oxidase I which has a low pH-optimum and cytochrome $c$ oxidase II which has a high $\mathrm{pH}$-optimum. The isolation and purification of each of these two cytochrome $c$ oxidases from iron-grown $T$. ferrooxidans were carried out.

\section{Purification}

All steps of the purification process were carried out at $4^{\circ} \mathrm{C}$ unless indicated otherwise. Since the activity decreased during storage at $4^{\circ} \mathrm{C}$ by freezing, particularly cytochrome $c$ oxidase I, five percent of glycerol was always added to each of the buffer solutions. The cause(s) of the activity loss has not yet been clarified, however, some aggregations were observed in preparations after loss of activity.

The harvested cells were washed five times with cold $0.01 \mathrm{~m}$ potassium phosphate buffer, pH 7.5 and disrupted by sonic oscillation $(20 \mathrm{kHz})$ in buffer for 10 minutes. A red colored cell-free crude extract was obtained, which was further centrifuged at $105,000 \times g$ for 90 minutes, and an orange colored supernatant $(105,000 \times g$ supernatant $)$ and a red colored particulate fraction $(105,000 \times g$ precipitate) were obtained, as described previously. ${ }^{9)}$

The effect of $\mathrm{pH}$ on the activity of cyto- 


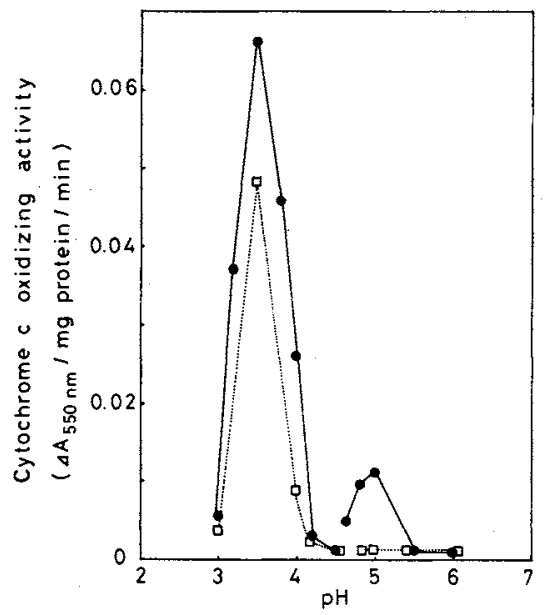

FIG. 4. Effect of $\mathrm{pH}$ on the Activity of Cytochrome $c$ Oxidase of $105,000 \times g$ Particulate- and $105,000 \times g$ Soluble-fraction.

The activity of cytochrome $c$ oxidase was measured by Method 2 as described in Materials and METHODS. $-105,000 \times g$ particulate fraction; $\square \cdots \square$, $105,000 \times g$ supernatant fraction.

chrome $c$ oxidase was measured for each of the two fractions, with reduced mammalian cytochrome c. As shown in Fig. 4, two pH-activity peaks were also observed in $105,000 \times g$ precipitate fraction which was composed of a plasma membrane, as described previously. ${ }^{9)}$ On the contrary, only one $\mathrm{pH}$ activity peak was observed at $\mathrm{pH} 3.5$, in case of the $105,000 \times g$ supernatant fraction. When the $105,000 \times g$ precipitate fraction was again suspended in $0.1 \mathrm{M}$ potassium phosphate buffer, $\mathrm{pH} 7.5$ and was disrupted by sonic oscillation $(20 \mathrm{kHz})$ in buffer for 10 minutes, almost all the cytochrome $c$ oxidase I was solubilized in the $105,000 \times g$ supernatant fraction, but the cytochrome $c$ oxidase II still remained in the $105,000 \times g$ precipitate fraction (data not shown). From the results it can be said that cytochrome $c$ oxidase I may be solubilized easily from the membrane without the aid of any detergents.

\section{Purification of cytochrome $c$ oxidase I}

Table I shows the summary data in the purification procedure on cytochrome $c$ oxidase I. The $105,000 \times g$ supernatant fraction was used for the starting material, in which solid ammonium sulfate was added slowly to give a 0.4 saturation. After this addition, stirring was continued for 30 minutes. The precipitate thus formed was gathered by centrifugation at $10,000 \times g$ for 20 minutes, redissolved in a minimal volume of $0.1 \mathrm{M}$ phosphate buffer, $\mathrm{pH} 7.5$ and dialyzed overnight against the same buffer. The orange colored and slightly turbid solution from the previous step was subsequently applied to a column $(3.3 \times 35 \mathrm{~cm})$ of Sephadex G-200 equilibrated with the same buffer. A yellow and slightly green colored active fraction was eluted at the void volume, which was again applied to a column $(3.3 \times 35 \mathrm{~cm})$ of Sephadex G-200 equilibrated with the same buffer. The activity peak was coincident with the peak of protein. The procedure gave about a 5 -fold purification over the $105,000 \times g$ supernatant fraction, judging from the activity for reduced mammalian cytochrome $c$, or a 3.5-fold purification judging from the difference in absorbance between $597 \mathrm{~nm}$ and $620 \mathrm{~nm}$ of $\alpha$-band of $a$ type cytochrome.

The fraction was applied to polyacrylamide disc gel electrophoresis. But the main protein fraction did not enter not only into $7.5 \%$ gel

Table I. Summary Data at Purification Steps for Cytochrome $c$ OXIDASE I FROM IRON-GROWN $T$. ferroxidans

\begin{tabular}{|c|c|c|c|c|}
\hline \multirow{2}{*}{ Steps } & \multirow{2}{*}{$\begin{array}{l}\text { Total protein } \\
\quad(\mathrm{mg})\end{array}$} & \multicolumn{2}{|c|}{ Specific activity } & \multirow{2}{*}{$\begin{array}{l}\text { Total activity } \\
\Delta A_{550 \mathrm{~nm}} / \mathrm{min}\end{array}$} \\
\hline & & $\Delta A_{550 \mathrm{~nm}} / \mathrm{mg} / \mathrm{min}$ & $\Delta A_{(597 \sim 620 \mathrm{~nm})} / \mathrm{mg}$ & \\
\hline $105,000 \times g$ Supernatant & 795 & 0.013 & 0.0035 & 10.34 \\
\hline $\mathrm{Am}_{2} \mathrm{SO}_{4}$ Fractionation & 260 & 0.015 & 0.0067 & 3.90 \\
\hline 1st Sephadex G-200 & 130 & 0.062 & 0.0120 & 8.06 \\
\hline 2nd Sephadex G-200 & 100 & 0.066 & 0.0125 & 6.66 \\
\hline
\end{tabular}




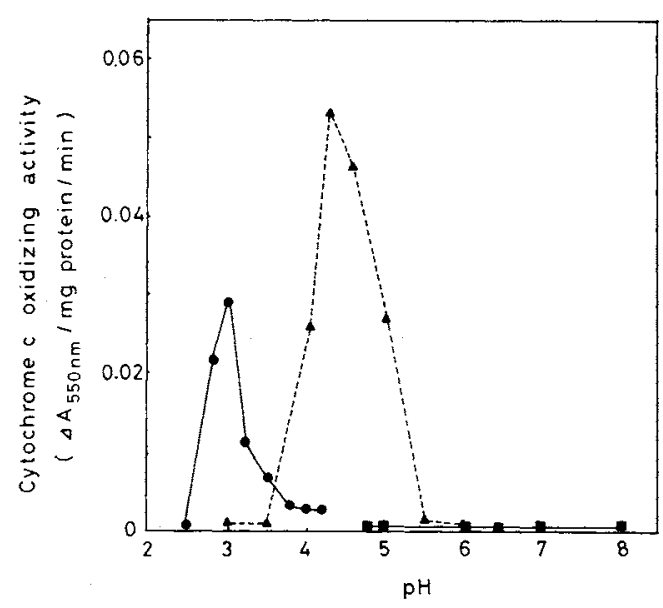

FIG. 5. Effect of $\mathrm{pH}$ on the Activity of Partially Purified Cytochrome $c$ Oxidase I.

The activity of cytochrome $c$ oxidase was measured by Method 2 as described in Materials and Methods.

- $0.1 \mathrm{~m} \beta$-Alanine sulfuric acid buffer; $\boldsymbol{\Lambda}-\mathbf{\Lambda}, 0.1 \mathrm{M}$ acetate bufter, $\mathbf{\square}, 0.1 \mathrm{~m}$ potassium phosphate buffer.

but also into $4 \%$ gel. In this way the enzyme has a tendency to aggregate in the process of purification and loses activity. Some detergents were used in an attempt to separate the aggregation, however, the enzyme was unstable to these detergents.

Effect of $\mathrm{pH}$ on cytochrome $c$ oxidizing activity was measured with the partially purified fraction. As shown in Fig. 5, the $\mathrm{pH}$ optimum of cytochrome $c$ oxidase I was at 3.0 in $0.1 \mathrm{M} \beta$-alanine-sulfuric acid buffer or 4.2 in $0.1 \mathrm{M}$ acetate buffer. No activity was observed above $\mathrm{pH} 4.8$. The results coincided well with the $\mathrm{pH}$-activity peak of iron-oxidase obtained in the same buffer (Figs. 1 and 2). The cause(s) of the $\mathrm{pH}$ shift in different buffers has not yet been clarified, however, it can be said that this was the main cause for the $\mathrm{pH}$-optimum of iron-oxidase to shift in different buffers (Figs. 1 and 2). From the results it can be said that the $\mathrm{pH}$-activity peak of cytochrome $c$ oxidase I has an important role in determining the $\mathrm{pH}$ activity peak of iron-oxidase, namely cytochrome $c$ oxidase I may be an important components of the iron-oxidizing system. It is reasonable for an iron-oxidizing bacterium, which grows in highly acidic conditions $(\mathrm{pH} 1 \sim 3$ ), to have such a low $\mathrm{pH}$ cytochrome $c$ oxidase.

\section{Purification of cytochrome c oxidase II}

The summary data on the purification of cytochrome $c$ oxidase II is shown in Table II. The $105,000 \times g$ precipitate fraction was used for the starting material, which was dialyzed sufficiently against deionized water. Solid sodium dodecyl (SDS) was added to the fraction (ratio of SDS-to-fraction $1: 1$ by weight), which was magnetically stirred for 30 minutes at $30^{\circ} \mathrm{C}$. The turbidity of the fraction was decreased markedly. Then the fraction was centrifuged at $105,000 \times g$ for 60 minutes, and an orange colored supernatant was obtained, which was subsequently applied to a column $(3.3 \times 35 \mathrm{~cm})$ of Sephadex G-200 equilibrated with $0.01 \mathrm{M}$ potassium phosphate buffer, $\mathrm{pH}$ 7.5 , supplemented with $0.05 \%$ SDS. The yellow and slightly green colored active fraction was eluted at the void volume, which was again applied to a column $(3.3 \times 35 \mathrm{~cm})$ of Sephadex G-200 equilibrated with the same buffer. The activity peak coincided with the peak of protein. The procedure gave a 7.6 -fold purification over the $105,000 \times g$ precipitate, judging from the activity for reduced mammalian cytochrome $c$. The effect of $\mathrm{pH}$ on

Table II. Summary Data at Purification Steps for Cytochrome $c$ OXIDASE II FROM IRON-GROWN $T$. ferrooxidans

\begin{tabular}{lccc}
\multicolumn{1}{c}{ Steps } & $\begin{array}{c}\text { Total protein } \\
(\mathrm{mg})\end{array}$ & $\begin{array}{c}\text { Specific acivity } \\
A_{550 \mathrm{~nm}} / \mathrm{mg} / \mathrm{min}\end{array}$ & $\begin{array}{c}\text { Total activity } \\
A_{550 \mathrm{~nm}} / \mathrm{min}\end{array}$ \\
\hline 105,000 $\times g$ Precipitate & 300 & 0.006 & 1.80 \\
Solubilization with SDS & 143 & - & -16 \\
1st Sephadex G-200 & 72 & 0.030 & 2.21 \\
2nd Sephadex G-200 & 48 & 0.046 & 2.16 \\
\hline
\end{tabular}




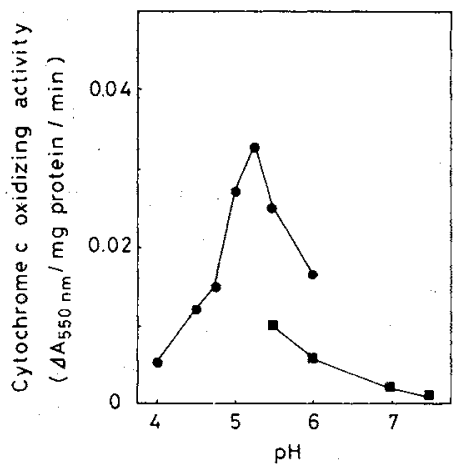

FIG. 6. Effect of pH on the Activity of Partially Purified Cytochrome $c$ Oxidase II.

The activity of cytochrome $c$ oxidase was measured by Method 2 as described in Materials and Methods. $\mathbf{0}, 0.1 \mathrm{M}$ acetate buffer; $\mathbf{-}-\mathbf{\square}, 0.1 \mathrm{M}$ potassium phosphate buffer.

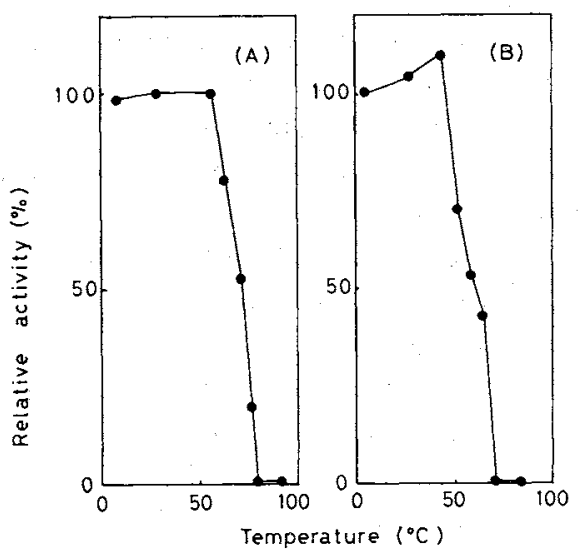

FIG. 7. Heat Stability of Partially Purified Cytochrome $c$ Oxidase I and II.

(A) The activity of cytochrome $c$ oxidase I was assayed in $0.1 \mathrm{M} \beta$-alanine sulfuric acid buffer, $\mathrm{pH} 3.0$, by Method 2 as described in MATERIALS AND MeTHods. (B) The activity of cytochrome $c$ oxidase II was also assayed by Method 2 in $0.1 \mathrm{M}$ phosphate buffer, $\mathrm{pH} 5.2$.

cytochrome $c$ oxidizing activity was measured with the partially purified fraction. As shown in Fig. 6, the pH-optimum of cytochrome $c$ oxidase II was at 5.2, which was nearly coincident with the small $\mathrm{pH}$-activity peak in Figs. 2 and 3 , but not with the $\mathrm{pH}$-activity peak of cytochrome $c$ oxidase I. In this way two distinct cytochrome $c$ oxidases were partially purified from iron-grown $T$. ferrooxidans.

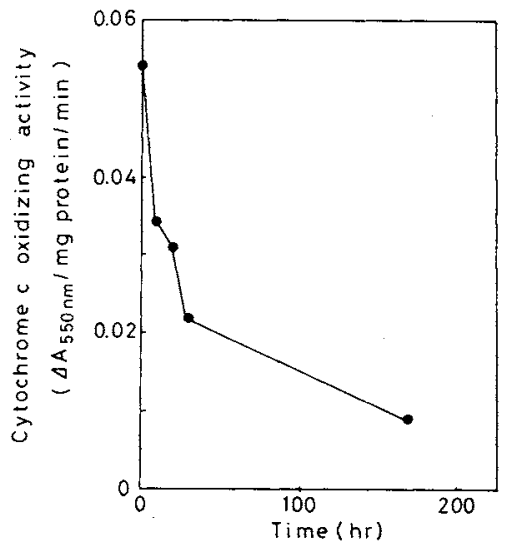

FIG. 8. Effect of Pronase on the Activity of Cytochrome $c$ Oxidase I.

Two milligrams of pronase was added to $2 \mathrm{ml}$ of the partially purified cytochrome $c$ oxidase I solution which was solubilized in $0.1 \mathrm{M}$ phosphate buffer supplemented with $5 \%$ glycerol, $\mathrm{pH} 7.5$ and incubated at $28^{\circ} \mathrm{C}$. Aliquots $(0.1-\mathrm{ml})$ of the solution were withdrawn, and the activity was assayed in $0.1 \mathrm{M} \beta$-alanine sulfuric acid buffer, pH 3.0, as described in MATERIALS AND METHODS.

\section{Proteinous nature of cytochrome $c$ oxidase I and $I I$}

The heat stability of cytochrome $c$ oxidase I and II was measured by heating them in a water bath at different temperatures for 10 minutes. As shown in Fig. 7, each cytochrome $c$ oxidase was heat labile, with cytochrome $c$ oxidase I losing almost all activity after 10 minutes at $80^{\circ} \mathrm{C}$ and with cytochrome $c$ oxidase II $72^{\circ} \mathrm{C}$. Chemical oxidation of reduced mammalian cytochrome $c$ was high at $\mathrm{pH} 3.0$, but not at $\mathrm{pH}$ 5.2. Though the 10 minute boiled enzyme solution was always used in each control to exclude chemical oxidation as described before, it was deemed necessary to further establish the proteinous nature of cytochrome $c$ oxidase I. As shown in Fig. 8, pronase markedly destroyed the activity of cytochrome $c$ oxidase I.

\section{Inhibition by cyanide, azide and silver ion}

All these compounds inhibited the ironoxidizing activity of this bacterium. Cyanide and azide are well-known inhibitors of cytochrome $c$ oxidase, and it has been shown that silver ions also inhibit the cytochrome $c$ oxi- 


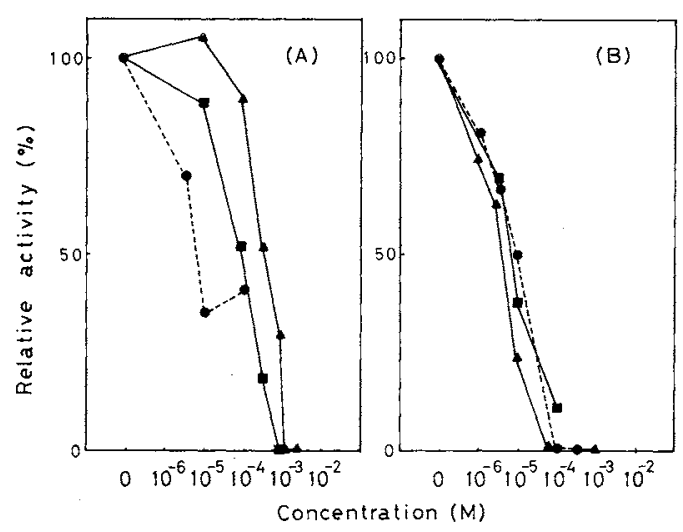

FIG. 9. Effect of Cyanide, Azide and Silver Ion on the Activity of Cytochrome $c$ Oxidase I and II.

The activity of cytochrome $c$ oxidase I (A) and activity of cytochrome $c$ oxidase II (B) were assayed in $0.1 \mathrm{M} \beta$ alanine sulfuric acid buffer, $\mathrm{pH} 3.0$, as described in Materials and Methods. $\mathbf{A}-\mathbf{A}$, cyanide; $\mathbf{\square}-\mathbf{D}$, azide; --- silver ion.

dase in the bacterium (data not shown). As shown in Fig. 9, the activity of cytochrome $c$ oxidase I was inhibited completely by cyanide at $10^{-3} \mathrm{M}$ or by azide at $10^{-3} \mathrm{M}$. Silver ions also inhibited the enzyme at $10^{-5} \mathrm{M}$, but a slight turbidity was observed at $10^{-4} \mathrm{M}$ concentration in the measured cell. The activity of cytochrome $c$ oxidase II was inhibited completely by cyanide, azide or silver ions at $10^{-4} \mathrm{M}$.

\section{Absorption spectra}

Figure 10 shows the absorption spectra of the partially purified cytochrome $c$ oxidase I and II from iron-grown $T$. ferrooxidans. The absorption maxima at 552, 525 and $418 \mathrm{~nm}$ are representative of the $\alpha-\beta$ - and $\gamma$-peaks of reduced $c$ type cytochrome. The absorption maxima at 597 and $440 \mathrm{~nm}$ (or shoulder) are representative of the $\alpha$ - and $\gamma$-peaks of reduced $a$ type cytochrome. No distinct difference on absorption spectrum was observed in these two cytochrome $c$ oxidases.

Cytochrome $c$ oxidase activity of iron glucose grown- or glucose salt grown- T. ferrooxidans The iron-oxidizing bacterium used in this study is a facultative iron-oxidizing bacterium,

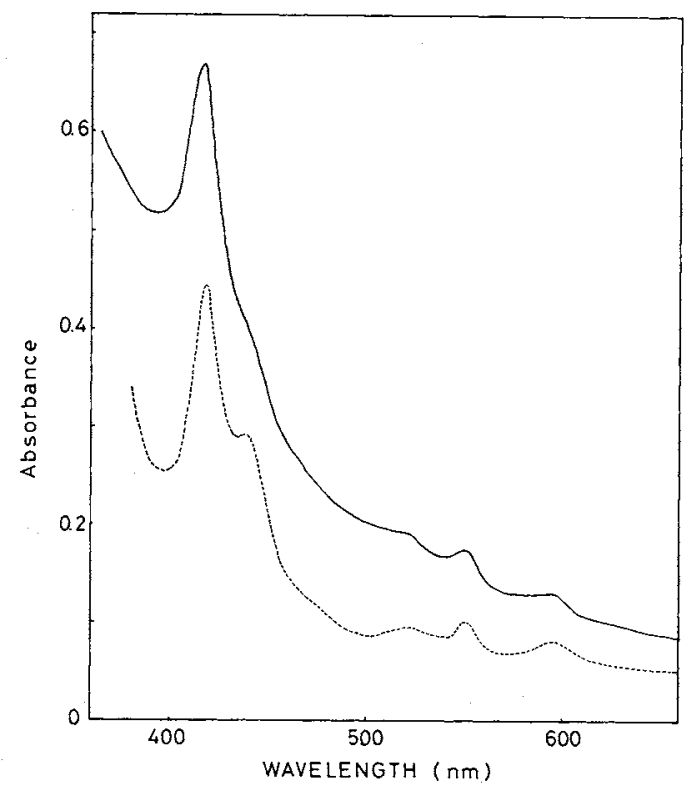

FIG. 10. Absorption Spectra of Partially Purified Cytochrome $c$ Oxidase I and II.

The concentration of every fraction was $1.5 \mathrm{mg}$ protein per ml. --.., cytochrome $c$ oxidase I; -...--, cytochrome $c$ oxidase II.

which obtains energy from both ferrous and organic substances. ${ }^{15)}$ As shown in Fig. 11, the iron-oxidizing activity and glucose oxidizing activity of the cell-free crude extracts were measured for iron-grown, iron-glucose grown or glucose-salt grown $T$. ferrooxidans. Cells grown to the late logarithmic stage of growth ( $5 \sim 6$ days cultivation for iron-grown cells and $6 \sim 7$ days cultivation for iron-glucose- or glucose-salt grown cells) were used in the experiments. Fig. 11(A) shows the results obtained with iron-glucose grown cells (mixotrophically grown cells). The value at zero glucose concentration shows the results of the iron-grown cells (autotrophically grown cells). Fig. 11(B) shows the results for glucose-salt grown cells (heterotrophically grown cells). Iron-oxidizing activity was markedly decreased in proportion to the amount of glucose added to the medium. Very low activity or no activity was observed in cells grown on media supplemented with glucose above $0.1 \%$ concentration. On the contrary, iron-grown cells constitutionally have comparatively high glu- 


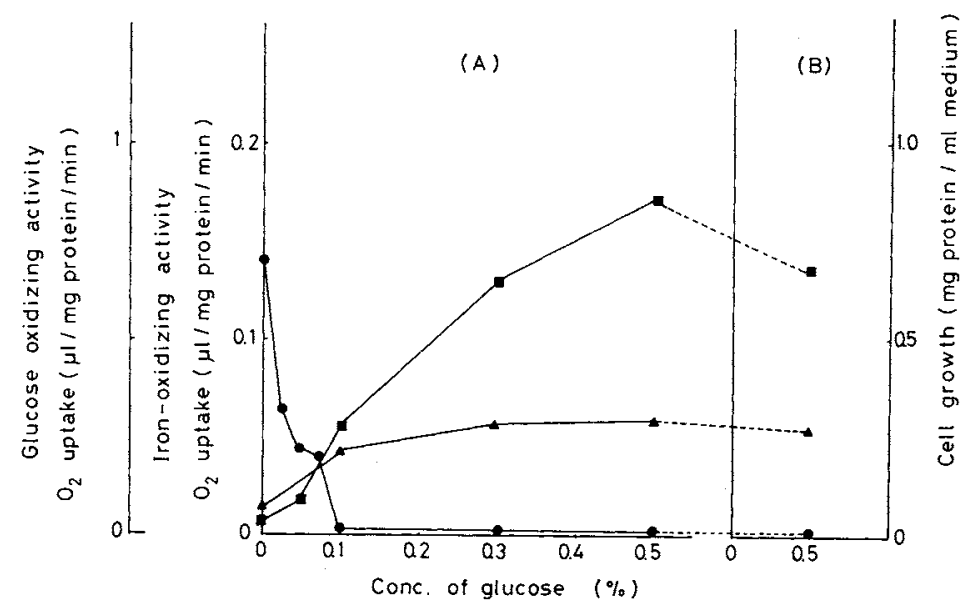

FIG. 11. Iron Oxidizing- and Glucose Oxidizing-activities of Iron-grown, Iron-glucose Grown and Glucosesalt Grown T. ferrooxidans.

(A) and (B) show the results obtained from iron ( $5 \%$ concentration)-glucose grown and glucose $(0.5 \%$ concentration)-salts grown cells, respectively. The abscissa showed the concentration of glucose supplemented with the media. The value at zero concentration of glucose in (A) shows the results for iron-grown cells. Each of the activities was measured with cell-free crude extracts as described in MATERIALS AND METHODS.

cose oxidizing activity, which was determined by oxygen uptake caused by the oxidation of glucose in a Warburg manometer. D-Glucose dehydrogenase and a terminal electron transport system (NADH: acceptor oxidoreductase and cytochrome $c$ oxidase) were involved in the glucose oxidation of cell-free crude extracts of the bacterium, as described previously. ${ }^{15)}$ It was observed that the glucose oxidizing activity of cells grown in mixotrophic or heterotrophic medium supplemented with $0.5 \%$ glucose increased only about 8 -fold more than autotrophically grown cells, namely the amount of change in glucose oxidizing activity in mixotrophic cells was comparatively small compared to iron-oxidizing activity. The cytochrome $c$ oxidizing activity of iron grown, iron-glucose $(0.05 \%$ of glucose $)$ grown, or glucose-salt $(0.5 \%$ of glucose $)$ grown cells was measured with each of the cellfree crude extracts. As shown in Fig. 12, the activity of cytochrome $c$ oxidase.I was markedly decreased in the order of autotrophic, mixotrophic and heterotrophic cells. The results correspond closely with that observed on iron-oxidizing activity of these cell. On the

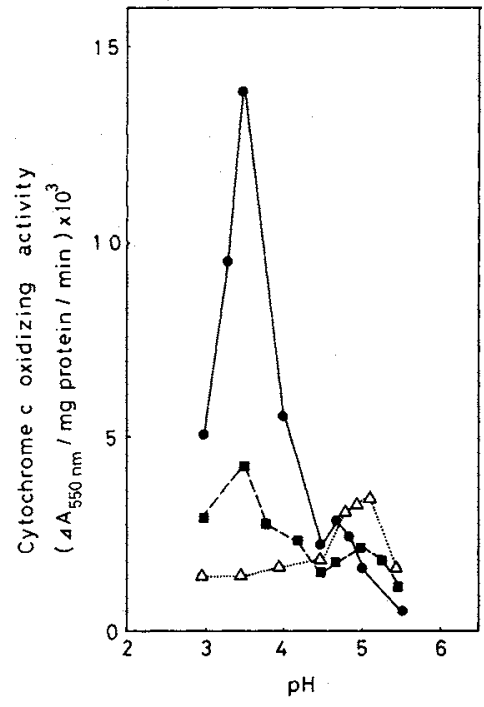

Fig. 12. Effect of $\mathrm{pH}$ on the Cytochrome $c$ Oxidizing Activity of Ion-grown, Iron-glucose Grown and Glucosesalt Grown T. ferrooxidans.

See the text for details. The activities of cytochrome $c$ oxidase were measured with each cell-free crude extract by Method 2, as described in Materials and Methods. - - Iron-grown cells; $\mathbf{D - -} \mathbf{-}$, iron-glucose $(0.05 \%)$ grown cells; $\triangle^{---\Delta} \Delta$, glucose $(0.5 \%)$-salt grown cells. 
contrary, the activity of cytochrome $c$ oxidase II was nearly constant in spite of the difference in energy sources used by the cells. The results also strongly suggests that the cytochrome $c$ oxidase I may be one essential component in iron-oxidase.

\section{DISCUSSION}

Two kinds of cytochrome $c$ oxidase were partially purified from iron-grown $T$. ferrooxidans. Both of them had a $\mathrm{pH}$-optimum in the acidic region, which is very reasonable for a bacterium that grows in acidic conditions, because an acidic condition is required for growth not only on autotrophic medium but also on mixotrophic or heterotrophic medium. Since the level and pH-optimum of the iron-oxidizing activity coincides closely with those of cytochrome $c$ oxidase I, the enzyme may play an important role in the iron-oxidizing system of the bacterium. On the other hand, cytochrome $c$ oxidase II seems to be involved in the heterotrophic electron transport system of cells: (a) the activity of cytochrome $c$ oxidase II is nearly constant in spite of the difference in energy sources used by the cells, which coincides with the results obtained on glucose oxidizing activity. (b) cytochrome $c$ oxidase was also partially purified from glucose-salt grown $T$. ferrooxidans, whose $\mathrm{pH}$-optimum was at 5.2. The value is the same as that of cytochrome $c$ oxidase II (data not shown). (c) the $\mathrm{pH}$-optima of the glucose oxidizing system, D-glucose dehydrogenase, and NADH oxidase (NADH: acceptor oxidoreductase) of iron-grown $T$. ferrooxidans were at 5.0, 5.5 and 5.0, respectively. ${ }^{15}$ ) The same results were obtained for glucose-salt grown cells. The $\mathrm{pH}-$ optimum of NADH: cytochrome $c$ reductase was at 5.2 to 5.5 for both iron-grown and glucose-salt grown cells (data not shown).

Though the purification of the two cytochrome $c$ oxidases in homogeneous state is difficult for reasons described before, comparisons of the properties of cytochrome $c$ oxidases should be examined further using homogeneous preparations. It is important to elucidate the acting order of these two cytochrome $c$ oxidases in the electron transport system of the bacterium and to determine whether the two kinds of cytochrome $c$ oxidase in the study correspond to the two cytochrome $a_{1}$ described by others. ${ }^{6,8)}$

\section{REFERENCES}

1) L. P. Vernon, H. Mangum, J. V. Beck and J. M. Shafia, Arch. Biochem. Biophys., 88, 227 (1963).

2) B. A. Blaylock and A. Nason, J. Biol. Chem., 238, 3453 (1963).

3) M. G. Yates and A. Nason, J. Biol. Chem., 241, 4872 (1966).

4) G. A. Din, I. Suzuki and H. Lee, Can. J. Biochem., 45, 1523 (1967).

5) G. A. Din and I. Suzuki, Can. J. Biochem., 45, 1547 (1967).

6) J. G. Cobley and B. A. Haddock, FEBS Lett., 60, 29 (1973).

7) J. C. Cox and D. H. Boxer, Biochem. J., 174, 497 (1978).

8) W. J. Ingledew and J. G. Cobley, Biochem. Biophys. Acta., 590, 141 (1980).

9) T. Sugio, T. Tano and K. Imai, Agric. Biol. Chem., 45, 393 (1981).

10) T. Sugio, T. Tano and K. Imai, Agric. Biol. Chem., 45, 405 (1981).

11) K. Imai, T. Sugio and T. Tano, Ferment Technol. Today., 521 (1972).

12) K. Imai, T. Sugio, T. Tsuchida and T. Tano, Agric. Biol. Chem., 39, 1349 (1975).

13) M. P. Silverman and D. G. Lundgren, J. Bacteriol., 77, 642 (1959).

14) O. H. Lowry, N. J. Rosebrough, A. L. Farr and R. J. Randall., J. Biol. Chem., 193, 265 (1951).

15) T. Sugio, Y. Anzai, T. Tano and K. Imai, Agric. Biol. Chem., 45, 1141 (1981). 